\title{
Operations research in the Netherlands *
}

\author{
C. Bernhard TILANUS \\ Department of Industrial Engineering, Eindhoven \\ University of Technology, P.O. Box 513, $5600 \mathrm{MB}$ \\ Eindhoven, Netherlands
}

\begin{abstract}
A questionnaire by telephone of $98 \%$ of the Netherlands Society for Operations Research personal membership is the basis for a description of their activities and for an extrapolation of OR/MS developments in a wide sense in a country like the Netherlands.
\end{abstract}

Keywords: Practice, Netherlands

\section{Introduction}

The title of this paper has some pretence, which should be explained. In the literature, one finds quite a number of papers entitled something like: "Operations research in ...", follows the name of a country, usually one of the smaller and more exotic ones. For examples, see $[3,5,7,9,10,11,13$, $14,15,16,20,21]$. On the other hand, one finds papers describing the application of operations research methods, based on empirical research and it turns out that a certain country has been implied, usually, of course, the U.S.A. For examples, see $[6,18,19,24,25]$.

What is the use of describing operations research in a certain country? The sad reason is, that $O R$ in different countries is developing along different paths, endangering the unity of the $O R$ world as incorporated in IFORS and EURO or even sailing under foreign colours such as, 'management science', 'decision science', 'cybernetics', 'automatic control' or 'information

\footnotetext{
* Paper presented at ORSA/TIMS Joint National Meeting. Orlando, FL, U.S.A., 7-9 November 1983.
}

Received September 1983; revised November 1983

North-Holland

European Journal of Operational Research 18 (1984) 220-229 processing'. If we want to defend the common ground of OR, first we need to be aware what is the ground where operations researchers in different parts of the world stand.

What is a sound basis for describing $O R$ in a country? Often, descriptions are subjective, based on a personal view and experience. For examples, see $[3,5,10,12,14,15,16,17,20,21]$. This approach is perfectly legitimate if the author is an expert and authority in the field. It is unfortunate, for instance, that Bob Machol has not published in the regular OR literature more than a few bits in Interfaces and [12] on $O R$ in various European countries in the period 1979-1981 when he was stationed in London as Liaison Scientist to the American Office of Naval Research, at the same time writing hundreds of pages on this topic in European Scientific Notes, which are freely accessible but beyond the horizon of most OR workers in Europe.

Sometimes, descriptions are more objective, based on empirical research-analysis of the literature, analysis of OR education, analysis of cases, interviews, written or oral questionnaires. For examples, see $[1,2,4,6,7,9,11,13,18,19,24,25]$. It seems as if especially Americans are fond of this approach. The problem with written questionnaires is that response is often so low as to detract from objectivity. Are people overquestionnaired and starting to hate forms that don't accommodate what they have to say? A written questionnaire from TIMS, for instance, had a response of 31\% [1] and one from the Belgian Society for the Application of Scientific Methods in Management only 10\% [2]. Many written questionnaires used the Fortune list of largest firms for a mailing list. They had responses like $16 \%$ [6], 19\% [18], 23\% [24] or $16 \%$ [25].

The present article is based on an oral questionnaire, by telephone, of $98 \%$ of the Dutch operations research population as organized in the Netherlands Society of Operational Research (NSOR). This does not cover all operations research applied by non-members and all quantitative methods in management applied under all sorts of fancy names but, if compared to other articles carrying similar titles, this seems enough 
introductory justification to warrant the encompassing title of this article.

The order of presentation is as follows. In Section 2 the aim and organization of the questionnaire are detailed. Sections 3-7 deal with results; i.e., respectively, personal characteristics of NSOR members (3), the relation between $O R$ and economic activities (4), OR activities themselves (5), the link between OR and computers (6), and developments in the Netherlands (7). Summary and conclusions are given in Section 8.

\section{Aims and setup of the questionnaire}

The primary reason for wanting to call up all members of the Netherlands Society of Operational Research (NSOR) was not to perform the questionnaire, but to discuss a possible contribution to the NSOR 25th anniversary collection of papers [23], just like the previous time, three and a half years before, the primary reason was not the questionnaire [22], but the raising of funds for the EURO III conference.

The oral invitation resulted in 36 members or $10 \%$ of the membership writing a contribution to the anniversary volume, details of which are given in the first chapter of [23]. If a similar approach had been followed with the ORSA/TIMS membership with the same proportions. this would have resulted in a collection of 1200 papers! Once talking. I put my other questions. to whom all of my partners responded, only one or two of whom reluctantly. Incidentally, I tried to achieve two other aims:

(1) to find referees for the European Journal of Operational Research,

(2) to collect wish-slips from the members as regards the activities of NSOR.

Table 1 specifies some numbers regarding the questionnaire. In the three and a half years between the previous [22] and the present questionnaire, nearly a third of the membership was turned over. Bad news for male heterosexuals: only $2 \%$ of NSOR membership is female.

To set up a questionnaire by telephone. a cheap and efficient telephone service is needed and, perhaps, a small country. I reckoned an average of twenty minutes for each call: ten minutes to get the right person on the right number and ten minutes to talk to him. Moreover, it seemed un.
Table 1

Data about the questionnaire among the membership of the Netherlands Society of Operational Research (NSOR)

\begin{tabular}{|c|c|c|}
\hline & Number & Percentage \\
\hline Membership beginning 1978 & 467 & \\
\hline Withdrawals $1978-1981$ &.$/ 153$ & \\
\hline Entries 1978-1981 & 111 & \\
\hline Membership mid 1981 & 425 & \\
\hline $\begin{array}{l}\text { Institutional members, no per- } \\
\text { son's name mentioned }\end{array}$ & .47 & \\
\hline Members abroad &.$/ .8$ & \\
\hline Population & 370 & 100 \\
\hline Contacted and interviewed & 363 & 98 \\
\hline Female & 6 & 2 \\
\hline
\end{tabular}

wise to delegate the calls to an unknown secretary or student. Hence, a telephone questionnaire is time-consuming, but I found it rewarding.

\section{Personal data of NSOR members}

As for personal data of NSOR members, their age and their education were asked. (Amusingly, responcients needed, of all questions, the longest time to think of their age.)

Table 2 gives the two-way distribution. The average age is 40.6 years. Three and a half years earlier, it had been 40.0 years [22]. NSOR does not grow grey quickly, but NSOR is rather grey. Younger members should be recruited.

The average educational level is high, too high, I daresay. $85 \%$ have an academic title at least equivalent to a Master's degree; of those younger than 35 years, this is even $93 \%$. Compared to the fact that about $0.9 \%$ of the total population has a Master's degree (120000 in a population of 14 million), this indicates how learned a society NSOR is. (For some notes about Dutch university education see Section 3 of [22]. It should be added that, as of 1982, the Dutch government forced all universities to cut down all their programs leading up to the Master's degree to four years, with a maximum actual study time allowed to individual students of six years.)

Education is also very much biased towards mathematics and econometrics. (Econometrics includes 'business econometrics', which is synony- 
Table 2

Age and education of NSOR members

\begin{tabular}{|c|c|c|c|c|c|c|c|c|}
\hline \multirow[t]{2}{*}{ Age } & \multicolumn{6}{|c|}{ Education } & \multirow[t]{2}{*}{ Total } & \multirow[t]{2}{*}{ Percentage } \\
\hline & $\begin{array}{l}\text { Drs. } \\
\text { econo- } \\
\text { metr- } \\
\text { ics }\end{array}$ & $\begin{array}{l}\text { Drs. } \\
\text { mathe- } \\
\text { matics }\end{array}$ & $\begin{array}{l}\text { Ir. } \\
\text { mathe- } \\
\text { matics }\end{array}$ & $\begin{array}{l}\text { Ir. }^{b} \\
\text { other- } \\
\text { wise }\end{array}$ & $\begin{array}{l}\text { Drs. } \\
\text { other- } \\
\text { wise }\end{array}$ & $\begin{array}{l}\text { No } \\
\text { univer- } \\
\text { sity } \\
\text { degree }\end{array}$ & & \\
\hline $20-24$ & & 1 & 1 & & & 1 & 3 & 1 \\
\hline $25-29$ & 16 & 6 & 19 & 4 & 1 & 2 & 48 & 13 \\
\hline $30-34$ & 20 & 15 & 16 & 6 & 2 & 5 & 64 & 18 \\
\hline $35-39$ & 18 & 14 & 14 & 12 & 7 & 13 & 78 & 21 \\
\hline $40-44$ & 14 & 14 & 12 & 10 & 3 & 6 & 59 & 16 \\
\hline $45-49$ & 5 & 5 & 5 & 6 & 7 & 8 & 36 & 10 \\
\hline $50-54$ & 3 & 7 & & 9 & 4 & 7 & 30 & 8 \\
\hline $55-59$ & 1 & 3 & & 9 & 7 & 7 & 27 & 7 \\
\hline $60-64$ & 1 & 1 & & 4 & 2 & 3 & 11 & 3 \\
\hline$\geqslant 65$ & & 1 & & 1 & 4 & 1 & 7 & 2 \\
\hline Total & $\overline{78}$ & $\overline{67}$ & $\overline{67}$ & $\overline{61}$ & $\overline{37}$ & $\overline{53}$ & $\overline{363}$ & $\overline{100}$ \\
\hline Percentage & 21 & 18 & 18 & 17 & 10 & 15 & 100 & \\
\hline
\end{tabular}

aoctorandus degree $\approx$ Master's degree in non-engineering studies; higher degrees (Dr., Prof.) included.

b Ingenieur degree $=$ Master's degree in engineering studies; higher degrees (Dr. Ir., Prof.) included.

mous to operations research, in the Netherlands.) $58 \%$ have a degree in mathematics or econometrics; of those younger than 35 years, this is even $82 \%$. If this is perpetuated, and only $18 \%$ of NSOR members will be non-mathematicians and noneconometricians in the future, where has the original interdisciplinary character of OR then gone? If the answer is: into the interdisciplinary discipline of a university education in operations research, then surely this is a paradox.

\section{OR and economic activity}

Some questions were asked about the economic activities of NSOR members.

Figure 1 gives the geographical dispersion by provinces. $63 \%$ of the NSOR membership is employed in the 'Randstad' (Border town), the Western agglomeration including cities like Amsterdam, The Hague, Rotterdam and Utrecht. It seems that Utrecht, which is also a central railway junction, is a nice centre of gravity of geographical dispersion for the NSOR to hold its monthly afternoon meetings!

Table 3 gives employment by sectors and branches of industry. It is not surprising that agriculture, where only $6 \%$ of the Dutch population works, has $0 \%$ NSOR membership. Manufac- turing industry, where $30 \%$ of the population works, has 21\% NSOR membership-I find this percentage rather low. An OR society should be especially concerned about its percentage of academics. If this is too high or too low, the

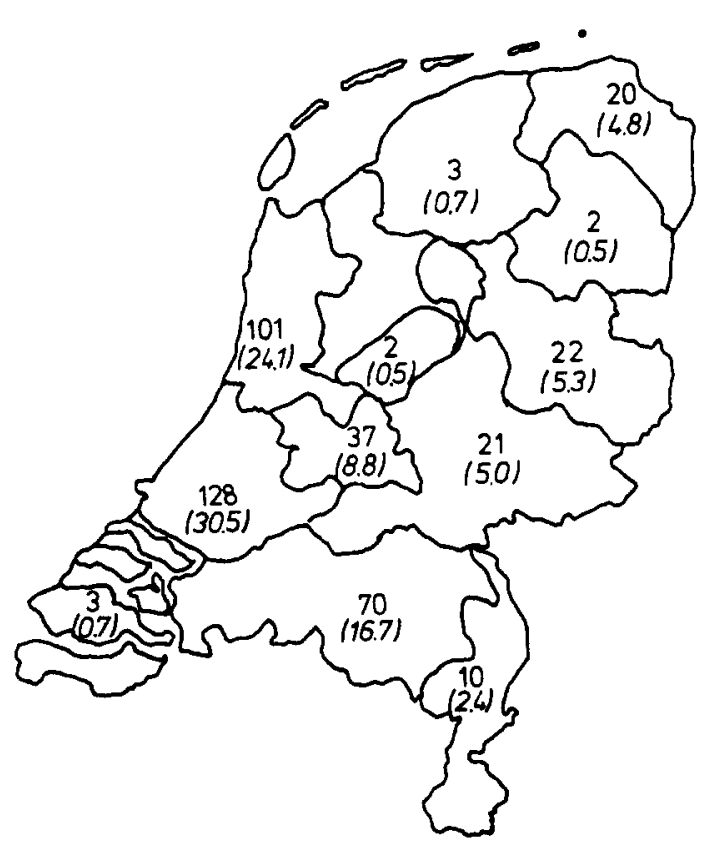

Fig. 1. Employment of NSOR members by provinces (institutional members included). Numbers in roman, percentages in italics and brackets. 
Table 3

Employment of NSOR members by sectors and branches of industry

\begin{tabular}{|c|c|c|c|}
\hline Sector/branch & $\begin{array}{l}\text { Number of } \\
\text { NSOR } \\
\text { members }\end{array}$ & Percentage & $\begin{array}{l}\text { Willing to } \\
\text { referee ar- } \\
\text { ticles and } \\
\text { review books } \\
\text { for EJOR }\end{array}$ \\
\hline
\end{tabular}

1. Primary sector (agriculture)

2. Secondary sector (manufacturing industry)

- process industry

- assembling industry

3. Tertiary sector (services)

- trade, transportation, etc.

- banks, insurance

- consultancy

4. Quartary sector (non-profit and government)

- central government

- local government

- research institutions

- higher professional education

- universities
2

57

29

45

30

$\underline{51}$

86
0

0

11

13

21

$\begin{array}{r}14 \\ 7 \\ \hline\end{array}$

$\begin{array}{rrr}11 & & 15 \\ 7 & & 14 \\ 13 & & 24\end{array}$

126

24

$\begin{array}{rr}4 & 5 \\ 3 & 3 \\ 8 & 19 \\ 4 & 5 \\ 29 & \frac{96}{205}\end{array}$

anstitutional members included.

possibilities of practitioners meeting theoreticians and educators are suboptimal. The present proportion of about three practitioners to two theoreticians (employment in research institutions, higher professional education and universities together being 41\%) works fine in our country, I think.

The last column of Table 3 specifies the number of people who declared their willingness to referee articles or review books for EJOR on specified topics. Almost $50 \%$ of the NSOR members are willing to perform such activities and even $83 \%$ of

Table 4

Firms/organizations with NSOR members

\begin{tabular}{ll}
\hline $\begin{array}{l}\text { Numbers of NSOR } \\
\text { members }(i)\end{array}$ & $\begin{array}{l}\text { Number of firms/organizations } \\
\text { with } i \text { NSOR members }\end{array}$ \\
\hline 1 & 113 \\
2 & 25 \\
3 & 9 \\
4 & 4 \\
5 & 5 \\
6 & $16^{\mathrm{a}}$ \\
& 172
\end{tabular}

\footnotetext{
These are named in Table 5.
}

the members in academia. I am pleased with such a quantity of Dutch names in my referees files, which unfortunately I have of no other country.

Table 5

Concentrations of NSOR members

\begin{tabular}{lc}
\hline Firm/organization & $\begin{array}{c}\text { Number of } \\
\text { NSOR members }\end{array}$ \\
\hline 1. Philips & 17 \\
2. Erasmus University of Rotterdam & 16 \\
3. Eindhoven University of Technology & 16 \\
4. Twente University of Technology & 15 \\
5. State University at Groningen & 14 \\
6. Tilburg University & 12 \\
7. Royal Dutch/Shell Group & 10 \\
8. Netherlands Organization for Applied & 10 \\
Scientific Research & 10 \\
9. University of Amsterdam & 9 \\
10. Ministry of Defence & 9 \\
11. Netherlands Railways & 8 \\
12. Delft University of Technology & 8 \\
13. Free University, Amsterdam & 7 \\
14. Hoogovens & 7 \\
15. Rabobank & 6 \\
16. Algemene Bank Nederiand & 174 \\
Total &
\end{tabular}


Apart from the facts that communication lines are shorter and I am more at home in the Netherlands, one reason that $I$ have far less referees from other countries must be the fact that no other OR society that I know of has had such a direct oral contact with its membership.

Table 4 considers firms/organizations and the number of their NSOR members. NSOR is represented in 172 firms/organizations. The average number of NSOR members is 2.4 per firm/organization. Particularly meaningful are the 113 firms/organizations that have just one NSOR member; it may be expected that these representatives are linking pins, communicating $O R$ and NSOR within their firm/organization.

Three and a half years earlier, fewer firms/organizations (158) were represented by more members (372) [22]. Have firms and other

Table 6

Dutch top-clubs and their NSOR members

\begin{tabular}{lrr}
\hline (a) Firms & Sales $1980^{\text {a }}$ & $\begin{array}{l}\text { Number of } \\
\text { NSOR members }\end{array}$ \\
\hline 1. Royal Dutch/Shell Group & 184.4 & 10 \\
2. Unilever & 51.5 & 5 \\
3. Philips & 36.5 & 17 \\
4. Gasunie & 19.0 & 2 \\
5. DSM & 14.9 & 3 \\
6. Estel & 14.0 & 7 \\
7. Akzo Group & 12.5 & 5 \\
8. NAM & 10.5 & 0 \\
9. SHV & 10.1 & 0 \\
10. V\&D & 8.4 & 2 \\
11. PTT & 8.2 & 5 \\
12. Nationale Nederlanden & 8.0 & 1 \\
13. Esso Nederland & 5.7 & 0 \\
14. AHOLD & 4.9 & 1 \\
15. Netherlands Railways & 4.3 & 9 \\
16. Chevron Nederland & 4.1 & 0 \\
\hline
\end{tabular}

(b) Banks

Assets $1980^{\circ}$

1. Algemene Bank Nederland
2. Rabobank
3. Amsterdam-Rotterdam Bank
4. NMB-bank
5. WUH-bank

(c) Universities

1. State University of Utrecht

2. University of Amsterdam

3. State University at Groningen

4. Leiden State University

5. Catholic University Nijmegen

6. Free University. Amsterdam

7. Delft University of Technology

8. Erasmus University of Rotterdam

9. Agricultural University, Wageningen

10. Tilburg University

11. Eindhoven University of Technology

12. Twente University of Technology

13. State University of Limburg

$\begin{array}{rr}108.7 & 6 \\ 97.6 & 7 \\ 94.3 & 3 \\ 47.9 & 3 \\ 16.7 & 0\end{array}$

Number of students ${ }^{b}$

$\begin{array}{rr}21.6 & 4 \\ 21.2 & 10 \\ 15.8 & 14 \\ 15.6 & 5 \\ 13.8 & 3 \\ 11.7 & 8 \\ 10.9 & 11 \\ 8.6 & 16 \\ 5.9 & 2 \\ 4.8 & 12 \\ 4.6 & 16 \\ 3.0 & 15 \\ 0.7 & 0\end{array}$

- Billions of guilders. Source: NRC-Handelsblad, 10 November 1981.

b Thousands. Source: Central Bureau of Statistics. 
organizations been economizing on multiple memberships?

Table 5 gives the 16 firms/organizations that have the largest numbers of NSOR members. They comprise nearly half of all NSOR members. Eight of them are universities. It is hoped that they will promote OR and NSOR in the Netherlands. Some Dutch firms are among the largest in the world. For instance, on the Fortune 1981 list of the 500 largest industrial corporations outside the U.S., Royal Dutch/Shell Group ranks first, Unilever 6th, Philips' Gloeilampenfabriek 10th, DSM 47th, Estel 53rd, Akzo Group 63rd and Esso Nederland $182 \mathrm{nd}$; on the list of the 50 largest commercialbanking companies outside the U.S., Algemene Bank Nederland ranks 25th, Rabobank 34th and Amsterdam-Rotterdam Bank 35th.

Table 6 puts it the other way round: firms/organizations are ranked according to some criterion of size-sales for business firms, assets for banks, number of students for universities-and their number of NSOR members are specified. It is seen that the latter have by no means the same ranking (except for banks). The more technologically oriented firms/organizations - Philips, PTT, Netherlands Railways; Twente and Eindhoven Universities of Technology-have a relatively large number of NSOR members.

\section{OR activities}

We come to the heart of the questionnaire: what do NSOR members do? This is indicated by the kind of department they work in, the problem areas they work on and the OR techniques they make use of.

Table 7 gives departments. After operations research departments proper, first come EDPdepartments, last come finance and administration and marketing departments. The low score of the latter two is ascribed to the usually non-quantitative education of administrators and marketers, not to the nature of the administrative and marketing functions.

Also the functions within the departments by sizes of departments are given. If NSOR members had been a random sample of the personnel of departments, the number of department heads expected in the sample would have been about 50 . Their actual number is nearly three times as large. Here again we probably have a linking pin phenomenon, department heads communicating $O R$ and NSOR to their co-operators.

Table 8 gives the average working time distribution of NSOR members over an exhaustive list of eleven problem areas. Some figures were surprisingly high to me: $40 \%$ for non-OR activities, $11 \%$ for information systems. Other figures were

Table 7

Departments and functions of NSOR members

\begin{tabular}{|c|c|c|c|}
\hline \multirow[t]{2}{*}{ (a) Kind of department } & \multicolumn{2}{|c|}{ NSOR members } & \\
\hline & Number & Percentage & \\
\hline Operations research, etc. & 149 & 41 & \\
\hline Electronic data processing & 69 & 19 & \\
\hline Organisation and efficiency & 38 & 10 & \\
\hline Planning, etc. & 38 & 10 & \\
\hline Finance and administration & 27 & 7 & \\
\hline Marketing and market research & 6 & 2 & \\
\hline \multirow[t]{2}{*}{ Various } & 36 & 10 & \\
\hline & $\overline{363}$ & $\overline{100}$ & \\
\hline (b) Size of department & head & co-operator & total \\
\hline $1-5$ & 42 & 19 & 61 \\
\hline $6-15$ & 54 & 92 & 146 \\
\hline $16-50$ & 28 & 60 & 88 \\
\hline \multirow[t]{2}{*}{$>50$} & 18 & 50 & 68 \\
\hline & $\overline{142}$ & $\overline{221}$ & $\overline{363}$ \\
\hline
\end{tabular}


Table 8

Average percentage working time distribution over eleven problem areas

\begin{tabular}{lc}
\hline Problem area & Percentage \\
\hline 1. Anything outside OR & 39.5
\end{tabular}

\section{Indirect $O R$}

2. Teaching $O R$

3. Research in OR (theoretical)

8.6

4. Standard software of OR (development)

5. Management of OR (e.g., management of an OR department)

Direct, executive $O R$

6. External, short term (purchasing, selling, marketing incl. market research, physical distribution, routing problems)

7. Internal, short term (materials management, inventory management, production planning, logistics management, scheduling and sequencing problems)

8. Project planning (planning and management of projects in the areas of maintenance, innovation, research and development, etc.)

9. Planning one or more years ahead (medium term and long term planning, strategic planning, personnel planning, location problems)

10. Financial planning (budgeting, cost-benefit analysis, investment analysis, portfolio management)

11. Information systems (development of management information systems, decision support systems)

$\overline{100}$

- Tables 8,9 and 12 of this paper are also partly used in chapter 1 of C.B. Tilanus. O.B. de Gans and J.K. Lenstra (eds.), Kwantitatieve methoden in het management, Aulapaperback 69. Spectrum. Utrecht, 1983; English translation to be published by Wiley in 1984 under the title: Quantitative Methods in Management: 36 Failures and Successes; used with permission of the publishers.

surprisingly low: $2 \%$ for OR standard software development, $2 \%$ for project planning, $3 \%$ for external, short term OR, $4 \%$ for financial planning. Probably most people doing the latter four kinds of activities just don't become NSOR members.

The data underlying Table 8 reveal that 94 NSOR members (26\%) professed to be working outside OR between 81-100\% of their time (it was left to the respondents to implicitly define what they understood by operations research); 21 NSOR members $(6 \%)$ spent $81-100 \%$ of their time on information systems.
Table 9 specifies OR techniques dealt with in practice, teaching and research, respectively, ranked by the number of times they have been mentioned for practice. No exhaustive list had been drawn up in advance, hence overlaps occur (e.g., mathematical programming is usually called by a more specific name). It is seen that the rankings for teaching and research differ from the ranking for practice but, given all we know about the practice, teaching and research of $O R$, the table is more a confirmation than a surprise.

\section{OR and computers}

Three questions referred to the role of computers in OR, which according to my hypothesis, could not be overestimated. Only 15 NSOR members that professed to be active in OR did not use computers, either directly themselves or indirectly through the help of co-operators.

Table 10 specifies the computer makes used by NSOR members or their co-operators. To my mind, high figures occur for DEC and CDC and low for Univac. The trend towards mini- and microcomputers is not yet visible in these figures.

Table 11 specifies software packages used directly or indirectly. Many packages were mentioned once or twice-isn't the dividing line between standard OR software packages and ad hoc OR software rather vague?

Table 12 specifies computer languages used. Here the typical OR bias towards technical-scientific computing is most evident. Fortran has the overwhelming majority (although the Netherlands is said to be a bulwark of Algol). High scores were made, to my mind, for Pascal and APL; low scores for PL/ 1 and Lisp.

\section{Developments}

It is difficult to discuss developments of $O R$ in the Netherlands, because earlier surveys have not been made, as far as I know, except the one in the first half of 1978 [22]. Only three and a half years elapsed between the previous survey and the present one.

Figure 2 pictures the only quantity that is known from the beginning of organized $O R$ in the Netherlands: the development of NSOR member- 
Table 9

OR techniques dealt with in practice, teaching and research (number of times mentioned, with overlaps)

\begin{tabular}{llrr}
\hline Technique & Practice & Teaching & Research \\
\hline 1. LP (including mixed-integer programming) & 66 & 27 & 15 \\
2. Statistical methods & 58 & 9 & 5 \\
3. Simulation & 57 & 14 & 1 \\
4. Heuristics & 26 & 5 & 3 \\
5. Forecasting techniques & 24 & 5 & 3 \\
6. Project planning, networks & 17 & 10 & 8 \\
7. Queueing theory & 15 & 15 & 0 \\
8. Regression analysis & 14 & 2 & 10 \\
9. Non-linear programming & 12 & 12 & 5 \\
10. Dynamic programming & 9 & 16 & 1 \\
11. Inventory theory & 8 & 13 & 4 \\
12. Cost-benefit analysis & 8 & 0 & 8 \\
13. Multi-criteria decision making & 7 & 0 & 1 \\
14. Markov programming & 6 & 9 & 2 \\
15. Factor and cluster analysis & 6 & 0 & 4 \\
16. Scheduling, routing & 5 & 4 & 8 \\
17. Production planning (including MRP) & 4 & 4 & 2 \\
18. Stochastic processes & 4 & 7 & 1 \\
19. Probability theory & 4 & 4 & 3 \\
20. Fuzzy sets & 3 & 0 & 4 \\
21. Mathematical programming & 2 & 9 & \\
22. Combinatorial programming & 1 & 10 & \\
23. Control theory & 0 & 5 & \\
24. Game theory & 0 & & \\
\hline
\end{tabular}

Table 10

Computers used directly or indirectly

\begin{tabular}{lc}
\hline Computer make & $\begin{array}{l}\text { Number of } \\
\text { times mentioned }\end{array}$ \\
\hline IBM & 99 \\
DEC & 74 \\
CDC & 63 \\
Burroughs & 19 \\
Amdahl & 15 \\
ICL & 11 \\
Univac & 10 \\
HP & 8 \\
Honeywell-Bull & 8 \\
Ten other makes, each & $<5$ \\
\hline
\end{tabular}

Table 11

Software packages used directly or indirectly

\begin{tabular}{lc}
\hline Software package & $\begin{array}{l}\text { Number of } \\
\text { times mentioned }\end{array}$ \\
\hline SPSS & 52 \\
MPSX & 26 \\
APEX & 21 \\
NAG & 12 \\
GPSS & 6 \\
MPOS & 6 \\
LANDO & 5 \\
IMSL & 5 \\
Many other packages, each & $<5$ \\
\hline
\end{tabular}

Table 12

Computer languages used directly or indirectly

\begin{tabular}{ll}
\hline Computer language & $\begin{array}{l}\text { Number of } \\
\text { times mentioned }\end{array}$ \\
\hline Fortran & 144 \\
Algol & 57 \\
Basic & 49 \\
Pascal & 47 \\
APL & 42 \\
Cobol & 39 \\
Simula & 36 \\
PL/1 & 19 \\
Assembler (various) & 8 \\
RPG & 6 \\
C-language & 5 \\
Mark IV & 1 \\
Lisp & 1 \\
\hline
\end{tabular}

ship. Individual rises and falls can be explained by individual incidents but more important is the fact that membership stagnates since ten years ago. This can be ascribed in part to the world depression, but other factors are specific to NSOR:

- hardly any membership recruitment is done (except in 1978);

- no effort is made to promote OR through subuniversity education; a diploma in $O R$ offered by 


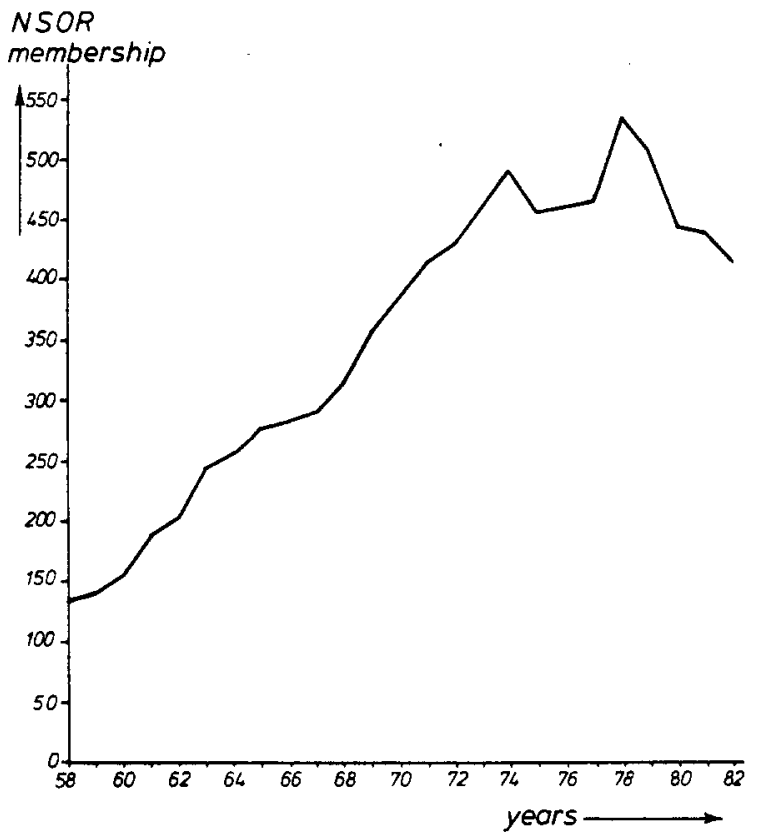

Fig. 2. NSOR membership development.

NSOR has such complicated examination rules and is so badly organized that only 27 people took it since 1965 - an average of 1.5 per year;

- the society has three publications, which is two too many for such a small society: a beautiful, red, monthly bulletin, $V v S$-bulletin; an informal, quick, blue periodical, Kwantitatieve methoden; and a would-be prestigious, English-language, green journal, Statistica Neerlandica. (NSOR is a section of the Netherlands Society for Statistics and Operations Research, which has 1200 members, but even so.);

- the contribution is too high; Dfl. 105 is about double the contribution of some other OR societies and therefore nearly exclusively full-time, specialised OR-workers (applied mathematicians and econometricians and academics) can be attracted; for 'part-time' OR-workers, managers interested in quantitative methods and other 'marginally' interested 'outsiders', Dfl. 105 'extra' is prohibitive.

Considering the turnover of one third of the membership in the three and a half years between the 1978 and 1981 surveys (cf. Table 1), if NSOR had fewer publications, lowered its prices and were more active in promoting $\mathrm{OR}$, it should be possible to retain more new and old members and grow by thirty per cent in three years!

Since the survey of 1981 was much more
Table 13

Some developments in NSOR between the surveys of 1978 and 1981 (percentages)

\begin{tabular}{lll}
\hline Quantity & 1978 & 1981 \\
\hline Mathematicians & 34 & 36 \\
Econometricians & 20 & 21 \\
Mathematicians and econometricians in age & & \\
classes below 35 & 73 & 82 \\
Members in manufacturing industry & 28 & 21 \\
Members in services & 20 & 31 \\
Members in educational institutions & 36 & 33 \\
\hline
\end{tabular}

elaborate than the 1978 one and since the time elapsed is short, it is not very rewarding to compare the two. In the present paper, only Tables 2 and 3 are comparable to Tables 3-6 of [22\}.

Table 13 specifies some developments of NSOR between the surveys of January-March 1978 and the second half of 1981 . I can only conclude: beware of the young mathematicians and econometricians and foster the members in manufacturing industry.

\section{Summary and conclusions}

Some itemized highlights of the results and conclusions of this study are as follows:

(1) A questionnaire by telephone of $98 \%$ of the membership of the Netherlands Society of Operational Research has been held. The aims were - to collect a 25th anniversary volume of case studies [23];

- to find referees and reviewers for EJOR:

- to collect feedback from the members about the activities of NSOR;

- to compile the statistical survey presented in this article.

(2) NSOR membership is 40.6 years of age on average and is dominated by mathematicians (36\%) and econometricians (21\%) (Table 2). The society should aim at more diversification in disciplines.

(3) Employment is predominantly in the quartary sector (47\%) with $29 \%$ employed in academia (Table 3 ). The secondary sector $(21 \%)$ should be reinforced.

(4) NSOR members probably fulfil linking-pin functions, transmitting $O R$ into their firms/ organizations (Tables 4, 7). For economies of scale, it would be preferable if their co-operators could 
be induced to become members themselves.

(5) Some NSOR members are not actively engaged in OR, hence, 'marginal' members or interested 'outsiders' (Table 8 ). This number could be multiplied if the society took account of this fact in its publication and contribution policy.

(6) The link between OR and computers is strong (Tables 10-12). It is good for society executives, conference organizers and journal editors to realize this.

(7) Many people are willing to perform activities for the society, specifically refereeing and reviewing, if only they are asked (Table 3 ).

(8) A questionnaire by telephone is time-consuming but rewarding. The aims have been achieved. It is recommended that other OR societies establish a similar contact with their membership.

(9) An OR society is probably like the visible tip of an iceberg: members representing their firms/organizations and many people performing operations research under different, fancy names without knowing. Nevertheless, this survey was deemed representative for OR in the Netherlands. For further research, it is recommended that a careful survey of national surveys be made to determine the common ground of current operations research.

\section{References}

[1] Abendroth, W.W., and Thornhill, V.T., "TIMS membership survey and CPMS assessment program", TIMS Business Office, Providence, RI, 1983.

[2] Belgian Society for the Application of Scientific Methods in Management, Questionnaire among the membership, 1983.

[3] Chi-fa, Ku, "Operations research in China", in: K.B. Haley (ed.), Operational Research 78. North-Holland, Amsterdam, 1979, 740-746.

[4] Dando, M.R., and Sharp, R.G., "Operational research in the U.K. in 1977: The causes and consequences of a myth?", Journal of the Operational Research Society 29 (1978) 939-949.

[5] Gasco, J.L., and Garcia, S. Rios, "Operations research in Spain", in: J.P. Brans (ed.), Operational Research ' 81 , North-Holland, Amsterdam, 1981, 197-208.

[6] Green, T.B., Newsom, W.B., and Jones, S.R., "A survey of the application of quantitative techniques to production/operations management in large corporations", Academy of Management Journal 20 (1977) 669-676.

[7] Jones, H.G., "Can OR learn from Sweden?", Operational Research Quarterly 27 (1976) 425-437.
[8] Kemball-Cook, D., and Wright, D.J., "The search for appropriate O.R.: A review of operational research in developing countries", Journal of the Operational Research Society 32 (1981) 1021-1037.

[9] Kurtulus, K., "Computer usage and employment of operations research techniques in Turkish industrial firms-a survey study", Paper presented at EURO V, Fifth European Congress in Operations Research, Lausanne, July 1982.

[10] Lasdon, L.S., "Operations research in China", Interfaces 10(1) (1980) 23-27.

[11] Lönnstedt, L., " The use of operational research in twelve companies quoted on the Stockholm stock exchange", Operational Research Quarterly 24 (1973) 535-545.

[12] Machol, R.E., “OR/MS in Europe-An American's impressions", in: J.P. Brans (ed.), Operational Research '81, North-Holland, Amsterdam, 1981, 209-218.

[13] Marinoff, G.M., “Operational research in twenty companies in Australian private industry", Operational Research Quarterly 26 (1975) 369-374.

[14] Matsuda, T., "The Japanese way of management", in: K.B. Haley (ed.), Operational Research '78, North-Holland, Amsterdam, 1979, 747-761.

[15] Min-Yi, Y., "Operations research in China", in: J.P. Brans (ed.), Operational Research '81, North-Holland, Amsterdam, 1981, 179-188.

[16] Mohan, L., and Bean, A.S., "Operational research in India: An evaluation of the current state of the art vis-à-vis potential", Operational Research Quarterly 27 (1976) 547-565.

[17] Morse, P.M., and Brown, A.A., "Operations research in the developing countries-A role for IFORS", in: K.B. Haley (ed.), Operational Research '75, North-Holland, Amsterdam, 1976, 111-124.

[18] Naylor, T.H., and Schauland, H., "A survey of users of corporate planning models", Management Science 22 (1976) 927-937.

[19] Radnor, M., and Neal, R.D., "The progress of management-science activities in large US industrial corporations", Operations Research 21 (1973) 427-450.

[20] Rosser, M.S., "O.R. in New Zealand", in: K.B. Haley (ed.), Operational Research '78, North-Holland, Amsterdam, 1979, 762-770.

[21] Thong-Ngee, G., and Himangshu, P., "Operational research in Singapore". in: J.P. Brans (ed.), Operational Research '81. North-Holland, Amsterdam, 1981, 189-195.

[22] Tilanus, C.B., "Snapshot of the Dutch O.R. society", European Journal of Operational Research 3 (1979) 1-5.

[23] Tilanus, C.B., Gans, O.B. de, and Lenstra, J.K., (eds.), Kwantitatieve Methoden in het Management, Aula-paperback 69, Spectrum, Utrecht, 1983; English translation to be published by Wiley, 1984, under the title: Quantitative Methods in Management: 36 Failures and Successes.

[24] Turban, E., "A sample survey of operations-research activities at the corporate level", Operations Research 20 (1972) 708-721

[25] Weston Jr., F.C., “Operations research techniques relevant to corporate planning function practices: An investigative look", Academy of Management Journal 16 (1973) 507-510. 